\title{
Integrative taxonomy: combining molecular and morphological characteristics to identify Lymnaea (Galba) cubensis, intermediate host of Fasciola hepatica
}

\author{
Taxonomia integrativa: combinando características moleculares e \\ morfológicas para identificar Lymnaea (Galba) cubensis, hospedeiro \\ intermediário de Fasciola hepatica
}

\author{
Ana Paula Pereira Neves Ferreira1; Andréia Luiza Oliveira Costa1; Raphael Meira Becattini; \\ Mônica Alves Neves Diniz Ferreira²; Hugo Pinto Rezende da Paixão3; Daniel Coscarelli3; \\ Teofânia Helena Dutra Amorim Vidigal3; Walter dos Santos Lima'; Cíntia Aparecida de Jesus Pereira1* (1) \\ ' Laboratório de Helmintologia Veterinária, Departamento de Parasitologia, Universidade Federal de Minas Gerais - UFMG, \\ Belo Horizonte, MG, Brasil \\ ${ }^{2}$ Laboratório Laboratório de Patologia Comparada, Departamento de Patologia, Universidade Federal de Minas Gerais - UFMG, \\ Belo Horizonte, MG, Brasil \\ ${ }^{3}$ Laboratório de Malacologia e Sistemática Molecular, Departamento de Zoologia, Universidade Federal de Minas Gerais - UFMG,
} Belo Horizonte, MG, Brasil

How to cite: Ferreira APPN, Costa ALO, Becattini RM, Ferreira MAND, Paixão HPR, Coscarelli D, et al. Integrative taxonomy: combining molecular and morphological characteristics to identify Lymnaea (Galba) cubensis, intermediate host of Fasciola hepatica. Braz J Vet Parasitol 2021; 30(2): e026320. https://doi.org/10.1590/S1984-29612021052

\begin{abstract}
Despite the epidemiological importance of the Lymnaeidae family regarding transmission of Fasciola hepatica, knowledge about the diversity and distribution of these molluscs and the role of each species in the expansion of fasciolosis remains sparse. Classical morphological $(n=10)$ identification was performed in lymneids from Lagoa Santa, a municipality in the state of Minas Gerais, Brazil, along with molecular and phylogenetic analysis $(n=05)$ based on the partial nucleotide sequences of the mitochondrial cytochrome c oxidase subunit I gene (COI mtDNA) and ribosomal internal transcribed spacer II (ITS-2 rDNA). The shell morphology made it possible to distinguish the lymneids of Lagoa Santa from Pseudosuccinea columella. Differences found in the penile complex and prostate shape allowed this species to be distinguished from Galba truncatula. However, the homogeneity of reproductive tract characteristics among Lymnaea (Galba) cubensis, L. viator and L. neotropica confirmed that these characteristics show low taxonomic reliability for identifying cryptic species. Genetic divergence analysis for the COI mtDNA gene and ITS-2 region of rDNA revealed greater similarity to Lymnaea (Galba) cubensis. Thus, correct species differentiation is important for monitoring the epidemiological risk of fasciolosis in the state of Minas Gerais, where cases of the disease have increased over recent years.
\end{abstract}

Keywords: Intermediate host, Trematoda, COI, ITS-2, morphology.

\begin{abstract}
Resumo
Apesar da importância epidemiológica da família Lymnaeidae na transmissão de Fasciola hepatica, o conhecimento sobre a diversidade e a distribuição desses moluscos e o papel de cada espécie, na expansão da fasciolose, ainda é escasso. Realizou-se a identificação morfológica clássica $(n=10)$ em limneídeos de Lagoa Santa, município do estado de Minas Gerais, Brasil, juntamente com a análise molecular e filogenética $(n=05)$, baseada nas sequências parciais de nucleotídeos do gene mitocondrial da subunidade I do citocromo c oxidase (COI mtDNA) e espaçador interno, transcrito do DNA ribossomal II (ITS-2 rDNA). A morfologia da concha possibilitou distinguir os limneídeos de Lagoa Santa de Pseudosuccinea columella. As diferenças encontradas no complexo peniano e na forma da próstata permitiram que essa espécie fosse distinta de Galba truncatula. No entanto, a homogeneidade das características do trato reprodutivo entre Lymnaea (Galba) cubensis, L. viator e L. neotropica confirmou que essas
\end{abstract}

Received November 12, 2020. Accepted April 23, 2021.

*Corresponding author: Cíntia Aparecida de Jesus Pereira. E-mail: cintiajp@icb.ufmg.br

This is an Open Access article distributed under the terms of the Creative Commons Attribution License, which permits unrestricted use distribution, and reproduction in any medium, provided the original work is properly cited. 
características apresentam baixa confiabilidade taxonômica para a identificação de espécies crípticas. A análise da divergência genética para o gene COI mtDNA e região ITS-2 do rDNA revelou maior similaridade entre os limneídeos de Lagoa Santa com Lymnaea (Galba) cubensis.

Palavras-chave: Hospedeiro intermediário, Trematoda, COI, ITS-2, morfologia.

\section{Introduction}

The etiological agent of fasciolosis, Fasciola hepatica (Linnaeus, 1758), is a trematode of the family Fasciolidae that parasitizes the liver and bile ducts of various domestic and wild mammalian species such as cattle, sheep, goats, horses and humans (Boray, 1969). Improving the current understanding regarding the relationship between $F$. hepatica and its definitive and intermediate hosts is becoming more urgent, given that the incidence of fasciolosis, a neglected and difficult to control zoonosis, is increasing in several regions of the world (MasComa et al. 2009).

The presence and dispersion of F. hepatica in the Brazilian state of Minas Gerais are worrisome. There have been reports of autochthonous cases of fasciolosis in buffaloes in São José da Lapa and Pedro Leopoldo (Dracz \& Lima, 2014) and of naturally infected cattle and molluscs in the southern part of the state (Itajubá and Careaçu) (Lima et al., 2009). Fasciolosis has also been founding in capybaras (Hydrochoerus hydrochaeris) living in the metropolitan region of Belo Horizonte, the capital of Minas Gerais (Dracz et al., 2016). These rodents live close to freshwater overlapping the area of occurrence with the lymneids molluscs - intermediate hosts of $F$. hepatica. Capybaras range from Panama through the eastern savannas of Colombia and Venezuela, to Brazil, Ecuador, Peru, Paraguay, Uruguay and northern Argentina (Reid, 2016). In addition, because of capybaras' seasonal migration, there is a real risk of dispersal of F. hepatica in Minas Gerais.

Despite the epidemiological importance of the Lymnaeidae family regarding transmission of $F$. hepatica, knowledge about the precise occurrence and distribution of these molluscs and the role of each species in the transmission of fasciolosis remains sparse. According to Correa et al.(2010), correct identification of the intermediate hosts is crucial for enabling characterization of areas at epidemiological risk and for improving the understanding of the evolution of Fasciola-Lymnaeidae interactions.

Currently, it is known that the lymneid species occurring in Minas Gerais include Pseudosuccinea columella, Lymnaea viator (Paraense, 1982a), Lymnaea (Galba) cubensis and Galba truncatula (Medeiros et al., 2014). Studies on morphological identification of lymnaeids are based on analyses on shell morphology and internal organ anatomy (radula, pallial complex and genital system). Although anatomical and morphological characteristics have been shown to clearly distinguish the species P. columella, Lymnaea diaphana and Galba cousini (Paraense, 1982b, 1984, 1995), they are only of limited use for identifying some molluscs of lymneids of the genus Galba because their shell morphology and internal anatomy are quite homogeneous (Paraense, 1976; Samadi et al., 2000; Correa et al., 2010).

Over the last decade, nucleotide sequence analysis, particularly of mitochondrial genes (mtDNA) and nuclear ribosomal genes (rDNA), has increasingly been used in determining the molecular systematics of mollusc groups, including lymneids. The most commonly used markers are mitochondrial cytochrome c oxidase subunit I (COI), ribosomal DNA of internal transcribed spacer region I (ITS-1), internal transcribed spacer II (ITS-2) and the 18S subunit, which provide specific and populational phylogenetic information (Bargues \& Mas-Coma, 2005; Correa et al., 2011)

Here, we used classical morphological taxonomy and molecular and phylogenetic analysis based on the partial nucleotide sequences of COI mtDNA and ITS-2 rDNA to thoroughly identify lymneids collected in Lagoa Santa, a municipality that is located within the metropolitan area of Belo Horizonte.

\section{Materials and Methods}

\section{Lymneid samples}

The lymneid molluscs used in this study were collected from the edges of the Lagoa Santa lake, in the municipality of Lagoa Santa, which is located within the metropolitan region of Belo Horizonte, Minas Gerais (19³8'54.2"S; $43^{\circ} 54^{\prime} 39.2^{\prime \prime}$ W). The molluscs collected were maintained in the veterinary helminthology laboratory of the Institute of Biological Sciences, Federal University of Minas Gerais. 


\section{Morphological characteristics}

Morphological identification of the molluscs was performed as described by Paraense (1976, 1982a, 1983), Samadi et al. (2000) and Correa et al. (2011). Fifteen adults specimens were anesthetized with a solution composed of $0.4 \mathrm{mg} / \mathrm{mL}$ of sodium pentobarbital (Hypnol-Cristalia) diluted in Chernin's balanced salt solution (CBSS; $47.7 \mathrm{mM}$ $\mathrm{NaCl} ; 2.0 \mathrm{mM} \mathrm{KCl} ; 0.49 \mathrm{mM}$ anhydrous $\mathrm{Na}_{2} \mathrm{HPO}_{4} ; 1.8 \mathrm{mM} \mathrm{MgSO}_{4} .7 \mathrm{H}_{2} \mathrm{O} ; 3.6 \mathrm{mM} \mathrm{CaCl} 2.2 \mathrm{H}_{2} \mathrm{O} ; 0.59 \mathrm{mM} \mathrm{NaHCO}$; $5.5 \mathrm{mM}$ glucose; and $3 \mathrm{mM}$ trehalose, $\mathrm{pH}$ 7.2). Next, a fragment of the cephalopodal region of five molluscs was excised for DNA extraction (see details in section 2.3). The cephalopodal fragments were fixed in pure alcohol and stored at $4{ }^{\circ} \mathrm{C}$ until the time of use. Then the molluscs were immersed in water at $70{ }^{\circ} \mathrm{C}$ for $30 \mathrm{~s}$, the body was separated from the shell and fixed in Raillet-Henry fluid ( $0.6 \%$ sodium chloride, $5 \%$ formaldehyde and $2 \%$ acetic acid) (Paraense, 1976) and 10 specimens were dissected with the aid of a stereoscopic microscope. The morphological characteristics of the shell and cephalopodal region and the morphology of the genital tract were observed. The remaining five mollusk specimens were cataloged and deposited in the Mollusc Collection of the Laboratory of Molecular Malacology and Systematics of the Department of Zoology, Federal University of Minas Gerais, under voucher access numbers 5089 to 5093.

\section{DNA extraction and polymerase chain reaction (PCR) protocol}

DNA from a total of five specimens was extracted from the cephalopodal fragment using the Wizard Genomic DNA purification kit (Promega, USA), following the manufacturer's guidelines. Partial sequences of the COI gene and fragment of the ITS-2 rDNA were obtained by sequencing PCR products. For COI, we used the universal primers LCO 1490 (5' GGTCAACAACTCATAAAGATATTGG 3') and HCO 2198 (5' TAAACTTCAGGGTGACCAAAAAATCA 3'), as described by Folmer et al. (1994). The amplification reaction was performed in a total volume of $20 \mu \mathrm{L}$, including 1 to $10 \mathrm{ng}$ of template DNA; buffer (1.5 mM MgCl$; 50 \mathrm{mM} \mathrm{KCl}$; and $10 \mathrm{mM}$ Tris- $\mathrm{HCl}, \mathrm{pH} 8.5) ; 200 \mu \mathrm{m}$ of each dNTP; $0.8 \mathrm{U}$ of Taq DNA polymerase (Promega, USA); and $5.0 \mathrm{pmol}$ of each primer. The PCR conditions were the following: an initial denaturation step at $95^{\circ} \mathrm{C}$ for $5 \mathrm{~min}$ and then cycles of denaturation at $94^{\circ} \mathrm{C}$ for $40 \mathrm{~s}$, at $46{ }^{\circ} \mathrm{C}$ for $1 \mathrm{~min}$ and at $72^{\circ} \mathrm{C}$ for $1 \mathrm{~min}$ (repeated for 38 cycles). Lastly, there was an elongation step at $72{ }^{\circ} \mathrm{C}$ for $10 \mathrm{~min}$.

For the ITS-2 rDNA fragment, we used the primers ITS2f (5' CGTCCGTCTGA GGGTCGGTTTGC 3') (Vidigal et al., 2000) and ETTS1 (5' TGCTTAAGTTCAGCGGGT 3') (Kane \& Rollinson, 1994), anchored to the 5.8S and 28S ribosomal genes, respectively. PCR amplification consisted of a final volume of $20 \mu \mathrm{L}$ including 1 to $10 \mathrm{ng}$ of template DNA; buffer (1.5 mM MgCl$; 50 \mathrm{mM} \mathrm{KCl}$; and $10 \mathrm{mM}$ Tris-HCl, pH 8.5); $200 \mu \mathrm{m}$ of each dNTP; $0.5 \mathrm{U}$ of Taq DNA polymerase (Promega, USA); and $1.0 \mathrm{pmol}$ of each primer. The PCR conditions were the following: $95^{\circ} \mathrm{C}$ for 3 min and then cycles of $95^{\circ} \mathrm{C}$ for $45 \mathrm{~s}, 60^{\circ} \mathrm{C}$ for $1 \mathrm{~min}$ and $72^{\circ} \mathrm{C}$ for $2 \mathrm{~min}$ (repeated for 32 cycles), and a final extension step at $72{ }^{\circ} \mathrm{C}$ for 5 min. A negative control (no DNA) and a positive control (with P. columella DNA) were included in all reactions. The amplified products $(2 \mu \mathrm{L})$ were viewed on $1 \%$ agarose gels with 1 XTAE buffer and staining with $1 \mu \mathrm{L}$ of GelRed ${ }^{\mathrm{TM}}$ (Biotium) plus $1 \mu \mathrm{L}$ of bromophenol blue.

\section{Purification and sequencing of PCR products}

After completion of the COI mtDNA and ITS-2 rDNA gene amplification reactions, the remaining PCR products (approximately $18 \mu \mathrm{L}$ ) were individually purified using the Agencourt AMPure XP kit (Beckman Coulter, USA), as directed by the manufacturer. After purification, the DNA concentration was estimated using the NanoDrop 2000c Spectrophotometer (Thermo Scientific, USA), in accordance with the manufacturer's guidelines. The purified products were stored in $0.2 \mathrm{~mL}$ microtubes at $4^{\circ} \mathrm{C}$ until use.

Purified amplifications of the COI mtDNA gene and ITS-2 rDNA fragment were subjected to DNA sequencing reactions by means of the Sanger method (Sanger et al., 1977), on the ABI3730 platform with BigDye v3.1 and the POP7 polymer (Life Technologies/ThermoFisher Scientific, USA), using PCR primers.

\section{Molecular analyses}

The sequences obtained were edited in ChromasPro (Technelysium Pty Ltd., Australia). To investigate similarities, we used the Basic Alignment Search Tools (BLAST) of the National Center for Biotechnology Information (NCBI), (National Library of Medicine, USA). Starting from the BLAST results, we selected the most similar congeneric sequences, with e-value 0.0 , derived from amplifications made using primers that included the "Folmer region" for the COI marker and the conserved ends of the $5.8 \mathrm{~S}$ and $28 \mathrm{~S}$ ribosomal genes for the ITS- 2 marker. The sequences 
were aligned using the ClustalW program, implemented in MEGA v.7.0 (Kumar et al., 2016). Estimates of genetic divergence for the COI and ITS-2 markers were made using the MEGA 7 software (Kumar et al., 2016), with the Kimura two- parameter substitution model (Kimura, 1980). The cutoff value taken to indicate evolutionary divergence was $4 \%$.

To build the phylogenetic tree, we used the best nucleotide substitution model. For ITS-2, this was determined to be $(K 2+G+I)$ and for COI, $(H K Y+G)$, based on the Bayesian information criterion in MEGA 7.0 (Kumar et al., 2016). Phylogenetic analyses were performed using maximum likelihood (ML) and Bayesian inference (BI) methods. ML trees were computed in MEGA version 7.0 and nodal support was estimated from 1000 bootstrap replications. BI analyses were performed in MrBayes v.3.2.6 (Ronquist et al., 2012) using the Markov Monte Carlo Chain (MCMC) search, in two simultaneous four-chain runs for 1,000,000 generations, with sampling every $100^{\text {th }}$ generation. The first $25 \%$ of the trees sampled were discarded as "burn-in". Each tree was viewed and edited using Fig Tree v.1.3.1 (Andrew Rambaut, 2007). Information on the sequences used in the molecular and phylogenetic analyses is presented in Table 1.

Table 1. Summary of the DNA sequences of limneids recovered from GenBank and used in molecular analyzes. Physa acuta was used as outgroup.

\begin{tabular}{|c|c|c|c|c|c|}
\hline \multirow{2}{*}{ Species } & \multirow{2}{*}{ Country:locality } & \multirow{2}{*}{ Coordinates } & \multicolumn{2}{|c|}{ Genbank acess } & \multirow{2}{*}{ References } \\
\hline & & & COI & ITS-2 & \\
\hline \multicolumn{6}{|c|}{ Galba cubensis } \\
\hline $\mathrm{Ha}$ & Cuba: Vaqueria & $\mathrm{N} 23^{\circ} 01^{\prime} ; \mathrm{W} 82^{\circ} 32^{\prime}$ & AM494009 & AM412223 & Bargues et al. (2007) \\
\hline HBA1 & Colombia: Barbosa & N 6 $24^{\prime} 38.4^{\prime \prime} ;$ W $75^{\circ} 24^{\prime} 2.7^{\prime \prime}$ & JN614391 & HQ283264 & Correa et al. (2011) \\
\hline HBA2 & Colombia: Barbosa & N 6 $24^{\prime} 38.4^{\prime \prime} ;$ W $75^{\circ} 24^{\prime} 2.7^{\prime \prime}$ & JN614392 & JN614462 & Correa et al. (2011) \\
\hline LCUSA1 & USA, Charleston & N $32^{\circ} 45^{\prime} 58.6^{\prime \prime} ;$ W $79^{\circ} 49^{\prime} 35.4^{\prime \prime}$ & JN614395 & JN614460 & Correa et al. (2011) \\
\hline LCUSA2 & USA, Charleston & N $32^{\circ} 45^{\prime} 58.6^{\prime \prime} ;$ W $79^{\circ} 49^{\prime} 35.4^{\prime \prime}$ & JN614394 & JN614459 & Correa et al. (2011) \\
\hline TePe_01 & USA & N 30॰ 04' 12.0"; W $94^{\circ} 12^{\prime} 00^{\prime \prime}$ & KT 781341 & $N A^{a}$ & Alda et al. (2018) \\
\hline Gcu_Equ_Lg2 & Ecuador & NA & NA & KT461815 & NA \\
\hline Gcu_Equ_LDP1 & Ecuador & NA & NA & KT461818 & NA \\
\hline \multicolumn{6}{|c|}{ Galba neotropica } \\
\hline $\mathrm{Ha}$ & Peru: Lima & $\mathrm{S} 12^{\circ} 02^{\prime} ; \mathrm{W} 76^{\circ} 56^{\prime}-77^{\circ} 08^{\prime}$ & AM494008 & NA & Bargues et al. (2007) \\
\hline $\mathrm{NtC2}$ & $\begin{array}{c}\text { Argentina: Mendoza } \\
\text { (Lineiro) }\end{array}$ & S $35^{\circ} 28^{\prime} 43^{\prime \prime} ;$ W $69^{\circ} 30^{\prime} 26^{\prime \prime}$ & JN872453 & NA & Standley et al. (2013) \\
\hline $\mathrm{NtC1}$ & $\begin{array}{l}\text { Argentina: Mendoza } \\
\text { (Lima) }\end{array}$ & 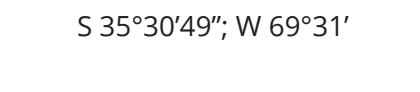 & JN872452 & NA & Standley et al. (2013) \\
\hline Gcu_Per_Olo & Peru: Ocõna & S 16²5'16.8"; W 736'55.8" & NA & KU870352 & Lounnas et al. (2017) \\
\hline Gcu_Per_Moq1 & Peru: Moquegua & S 17¹9'24.3"; W 7059’29" & NA & KU870350 & Lounnas et al. (2017) \\
\hline Tacuarembo & $\begin{array}{l}\text { Uruguay: } \\
\text { Tacuarembo }\end{array}$ & S $32^{\circ} 27^{\prime} ;$ W $56^{\circ} 17^{\prime}$ & NA & KX781344 & $\begin{array}{l}\text { Armúa- } \\
\text { Fernandez et al. } \\
(2016)\end{array}$ \\
\hline Paysandu & Uruguay: Paysandu & S $31^{\circ} 29^{\prime} ;$ W $57^{\circ} 52^{\prime}$ & NA & KX781343 & $\begin{array}{c}\text { Armúa- } \\
\text { Fernandez et al. } \\
(2016)\end{array}$ \\
\hline \multicolumn{6}{|c|}{ Galba viatrix } \\
\hline $\mathrm{Ha}$ & Argentina: Frias & $\mathrm{S} 40^{\circ} 14^{\prime} ; \mathrm{W} 64^{\circ} 10^{\prime}$ & AM494010 & AM412224 & Bargues et al. (2007) \\
\hline LVX2 & Argentina: Rio Negro & S $40^{\circ} 44^{\prime} 6,7^{\prime \prime} ;$ W $66^{\circ} 37^{\prime} 26.7^{\prime \prime}$ & JN614397 & HQ283265 & Correa et al. (2011) \\
\hline LVX3 & Argentina: Rio Negro & S $40^{\circ} 44^{\prime} 6,7^{\prime \prime} ;$ W $66^{\circ} 37^{\prime} 26.7^{\prime \prime}$ & JN614398 & JN614465 & Correa et al. (2011) \\
\hline
\end{tabular}

aNA: No evaluated. 


\begin{tabular}{|c|c|c|c|c|c|}
\hline \multirow{2}{*}{ Species } & \multirow{2}{*}{ Country:locality } & \multirow{2}{*}{ Coordinates } & \multicolumn{2}{|c|}{ Genbank acess } & \multirow{2}{*}{ References } \\
\hline & & & $\mathrm{COI}$ & ITS-2 & \\
\hline \multicolumn{6}{|c|}{ Galba truncatula } \\
\hline VEN_Mucu_04 & Venezuela: Mérida & N 849'12.0"; W 7048'36.0" & KT781318 & NA & Alda et al. (2018) \\
\hline VEN_Much_07 & Venezuela: Mérida & N $8^{\circ} 27^{\prime} 36.0^{\prime \prime} ;$ W 7110'48.0" & KT781317 & NA & Alda et al. (2018) \\
\hline VEN_Mica_09 & Venezuela: Mérida & N 841'24.0" ; W 7054'36.0" & KT781316 & NA & Alda et al. (2018) \\
\hline LVP1 & Venezuela: El sapo & N $8^{\circ} 52.4^{\prime} ; W 70^{\circ} 48^{\prime} 29.3^{\prime \prime}$ & NA & JN614443 & Correa et al. (2011) \\
\hline LVP2 & Venezuela: El sapo & N $8^{\circ} 52.4^{\prime} ; W 70^{\circ} 48^{\prime} 29.3^{\prime \prime}$ & NA & JN614447 & Correa et al. (2011) \\
\hline LVP3 & $\begin{array}{c}\text { Venezuela: Paso El } \\
\text { Cóndor }\end{array}$ & N 850'13.7"; W 7049'48.6" & NA & JN614445 & Correa et al. (2011) \\
\hline \multicolumn{6}{|c|}{ Galba schirazensis } \\
\hline $\mathrm{b}$ & Mexico & N $18^{\circ} 51^{\prime \prime} 46^{\prime \prime} ;$ W $98^{\circ} 26^{\prime} 33^{\prime \prime}$ & JF272608 & $J F 272602$ & Bargues et al. (2011) \\
\hline EQU_Nono_12 & Ecuador: Nono & S 0 0 $03^{\prime} 00.0^{\prime \prime} ;$ W 78³4'12.0" & KY198256 & NA & Lounnas et al. (2017) \\
\hline \multicolumn{6}{|c|}{ Galba cousini } \\
\hline LCM2 & Venezuela: Mucubaji & N 847'54"; W 7049'033.4" & JN614389 & HQ283266 & Correa et al. (2011) \\
\hline LCM3 & NA & NA & JN614388 & JN614466 & Correa et al. (2011) \\
\hline Physa acuta & México: Vera Cruz & NA & JN614369 & HQ283272 & Correa et al. (2011) \\
\hline
\end{tabular}

aNA: No evaluated.

\section{Results}

\section{Morphological characteristics}

In general, the shells of the lymneids sampled in Lagoa Santa presented a light to dark brown color, sometimes reddish, with a conical shape and an average length of $7.01 \pm 0.57 \mathrm{~mm}$ (range: $5.7-8.2)$. The shell opening was oval, measuring $3.55 \pm 0.32 \mathrm{~mm}$ (range: 2.8 - 4.4), and was half the length of the entire shell. The ratio length/ aperture width the shell was $2.14 \pm 0.31 \mathrm{~mm}$. The turns were slightly rounded, with gradually increasing diameter, convex turns and deep sutures (Figure 1A).

The mass of the cephalopodal region was pale and grayish. The eyes were black. The tentacles were elongated and pyramidal. The roof of the mantle was usually dark brown, with small light brown and unpigmented spots (Figure 1B).

The albumen gland had a rounded shape. The oviduct was sinuous and markedly wrinkled, with wide folds along its length (Figure 1E). The pouch of the oviduct was not evident or was under the oviduct. The nidamental gland was oblong, slightly flattened dorsoventrally, and narrowed into a short right-folding vagina. The spermduct was thin and ran parallel to the nidamental gland. The prostate had a large triangular oval-shaped granular surface, with a triangular affixed apex and a rounded base (Figure 1D). Next to the prostate was the narrow-diameter vas deferens, which connected to the penile complex. Before reaching this complex, the vas deferens went close to and was attached to the cephalopodal mass wall, thus making it difficult to dissect at this point. Regarding the penile complex, the length of the foreskin $(1.1 \mathrm{~mm})$ was slightly longer than the length of the penis sheath $(1.03 \mathrm{~mm})$, although in some specimens it was of the same size. The penis sheath was narrower in width than the foreskin and was of cylindrical shape with a small apical chamber (Figure 1C). The penile complex had one set of retractor muscles and one set of protractor muscles. The body of the spermatheca was oval and was located on the leftventral side of the pericardium. The ovotestis was compact and partially inserted into the digestive gland.

\section{Molecular analyses}

Amplification and sequencing were successful, both for COI (mtDNA) and for ITS-2 (rDNA) fragments. The sequences obtained were aligned with those of other molluscs lymneids, according to the criteria established, which were described in the Materials and Methods section. Estimates of genetic divergence are presented in Table 2. 

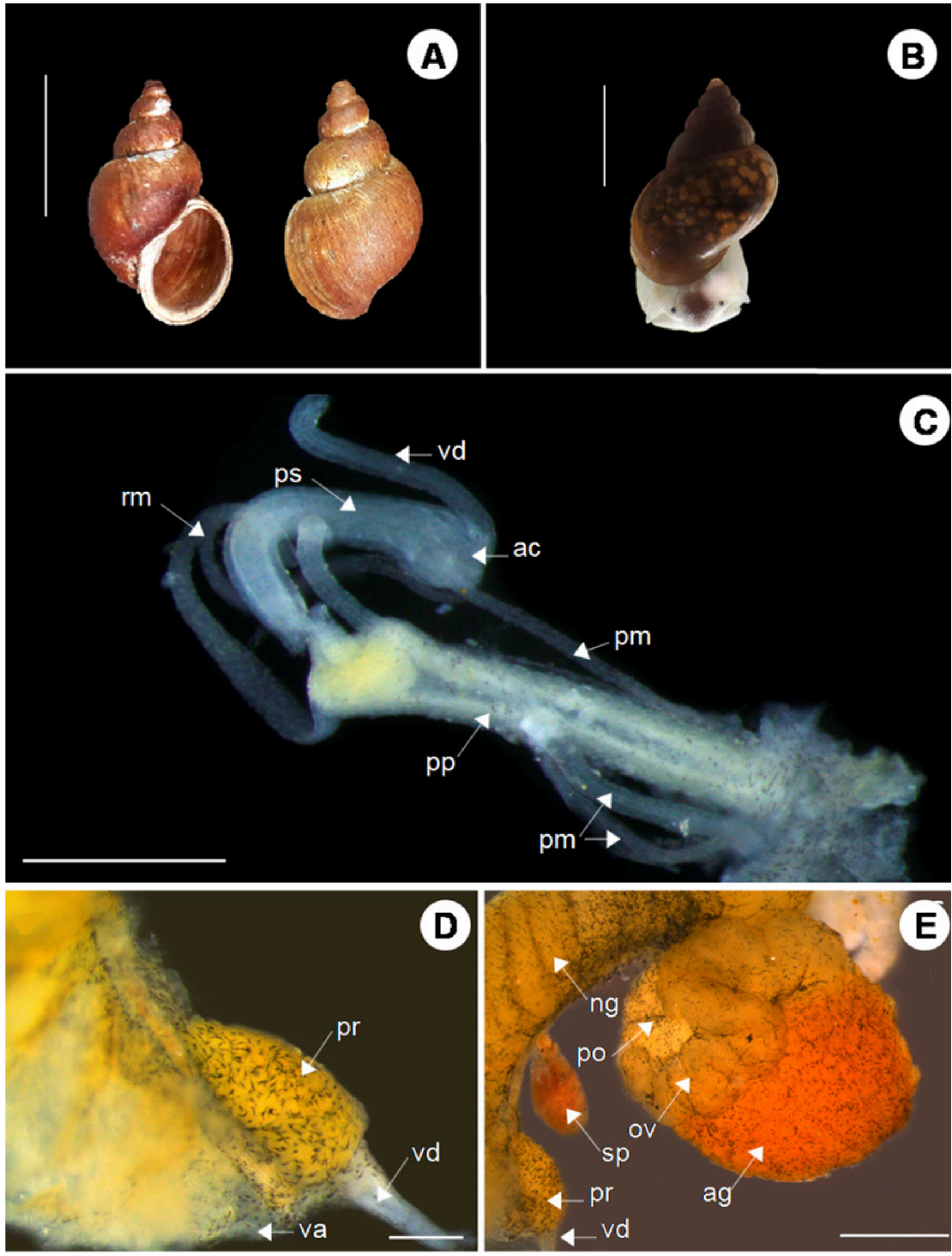

Figure 1. Lymneid molluscs from Lagoa Santa, Minas Gerais, Brazil (5.27 mm). (A)- Dorsal and ventral view of the shell (scale bar = $3 \mathrm{~mm}$ ); (B) In vivo specimen: note cephalopodal region, mantle stains (scale bar = $3 \mathrm{~mm}$ ); (C) Penile complex (scale bar $=500 \mu \mathrm{m}$ ); (D) Prostate region (scale bar = $200 \mu \mathrm{m}$ ); (E) Oviduct region (scale bar $=500 \mu \mathrm{m}$ ). Abbreviations for the structures: ac - apical sheath chamber; ag - albumen gland; ng - nidamental gland; ov - oviduct; pm - penile protractor muscle; op- oviduct pouch; pp - penis prepuce; pr- prostate; rm - penile retractormuscle; sp - spermatheca; va - vagina. 
Table 2. Estimates of genetic divergence (uncorrected p-distance, expressed as a percentage) between mitochondrial cytochrome c oxidase subunit I (COI mtDNA) and ribosomal internal transcript spacer region II (ITS-2 rDNA) gene sequences of Lymnaea (Galba) cubensis (in bold) from Brazil and cogeneric sequences available in the GenBank.

\begin{tabular}{|c|c|c|c|}
\hline & \multicolumn{3}{|c|}{ Lymnaea (Galba) cubensis BRA } \\
\hline & COI & & ITS-2 \\
\hline Galba cubensis (AM494009) CUB & $0.0 \%$ & Galba cubensis (AM412223) CUB & $0.7 \%$ \\
\hline G. cubensis (JN614391) COL & $0.0 \%$ & G. cubensis (HQ283264) COL & $0.7 \%$ \\
\hline G. cubensis (JN614392) COL & $0.0 \%$ & G. cubensis (JN614462) COL & $0.7 \%$ \\
\hline G. cubensis (JN614394) USA & $0.5 \%$ & G. cubensis (JN614459) USA & $0.7 \%$ \\
\hline G. cubensis (JN614395) USA & $0.5 \%$ & G. cubensis (JN614460) USA & $0.7 \%$ \\
\hline G. cubensis (KT781341) USA & $0.0 \%$ & G. cubensis (KT461815) EQU & $0.7 \%$ \\
\hline G. neotropica (AM494008) PER & $2.4 \%$ & G. cubensis (KT461818) EQU & $0.7 \%$ \\
\hline G. neotropica (JN872453) ARG & $2.4 \%$ & G. viatrix (AM412224) ARG & $3.5 \%$ \\
\hline G. neotropica (JN872452) ARG & $2.5 \%$ & G. viatrix (HQ283265) ARG & $3.5 \%$ \\
\hline G. viatrix (AM494010) ARG & $5.9 \%$ & G. viatrix (JN614465) ARG & $3.5 \%$ \\
\hline G. viatrix (JN614397) ARG & $5.9 \%$ & G. neotropica (KU870352) PER & $6.1 \%$ \\
\hline G. viatrix (JN614398) ARG & $5.9 \%$ & G. neotropica (KU870350) PER & $6.1 \%$ \\
\hline G. truncatula (KT781318) VEN & $12.3 \%$ & G. neotropica (KX781344) URU & $6.1 \%$ \\
\hline G. truncatula (KT781317) VEN & $12.3 \%$ & G. neotropica (KX781343) URU & $6.1 \%$ \\
\hline G. truncatula (KT781316) VEN & $12.3 \%$ & G. truncatula (JN614443) VEN & $14.4 \%$ \\
\hline G. schirazensis (JF272608) MEX & $12.7 \%$ & G. truncatula (JN614447) VEN & $14.4 \%$ \\
\hline G. schirazensis (KY198256) EQU & $12.9 \%$ & G. truncatula (JN614445)VEN & $14.4 \%$ \\
\hline G. cousini (JN614389) VEN & $11.5 \%$ & G. schirazensis (JF272602) MEX & $21.9 \%$ \\
\hline G. cousini (JN614388) VEN & $11.5 \%$ & G. cousini (HQ283266) VEN & $23.8 \%$ \\
\hline \multirow[t]{2}{*}{ Physa acuta (JN614369) MEX } & $22.7 \%$ & G. cousini (JN614466) VEN & $23.8 \%$ \\
\hline & & Physa acuta (HQ283272) MEX & $49.6 \%$ \\
\hline
\end{tabular}

In green, we highlight co-specific species, according to the cut off value of 4\%. Physa acuta was used as outgroup. BRA - Brazil; CUB - Cuba; USA - United States; COL - Colombia; PER - Peru; ARG - Argentina; VEN - Venezuela; MEX - Mexico; EQU - Ecuador.

The consensus sequence for this COI marker was 640 nucleotides [GenBank: MW915587] in size, consisting of $42 \%$ thymine, $13.8 \%$ cytosine, $25.6 \%$ adenine and $18.6 \%$ guanine. The sequence analyzed was $100 \%$ similar to Lymnaea (Galba) cubensis from Cuba [GenBank: AM494009], the United States [GenBank: KT781341] and Colombia [GenBank:JN614391, JN614392]. The average interspecific genetic distance was 5.8\%, nearly 37 times greater than the average intraspecific distance (0.16\%). With a genetic distance (GD) for COI of $4 \%$, taken as the cutoff value to define Lymnaeidae species, the analysis suggested that Lymnaea (Galba) cubensis and Lymnaea neotropica are co-specific (GD $=2.43 \%)$.

The consensus sequence for the ITS-2 marker was 560 nucleotides [GenBank: MW916936] in length, comprising $29.1 \%$ thymine, $29.1 \%$ cytosine, $14.1 \%$ adenine and $27.7 \%$ guanine. The sequence analyzed showed $99.3 \%$ similarity with $L$. (Galba) cubensis sequences from different countries in the neotropical region. The average interspecific genetic distance was $7.6 \%$, i.e. almost 11 times greater than the average intraspecific distance $(0.7 \%)$. With a genetic distance (GD) for ITS-2 of 4\%, taken as the cutoff value to define Lymnaeidae species, the analysis suggested that L. (Galba) cubensis and L. viator are co-specific $(G D=3.5 \%)$ for the sequences analyzed.

We found a high phylogenetic relationship between the lymneid samples studied here and L. (Galba) cubensis. The species L. (Galba) cubensis, L. viator and L. neotropica cluster in the same clade, being polyphyletic. The species G. truncatula, G. schirazensis and G. cousini were grouped in a distinct clade. The phylogenetic analyses based on COI mtDNA and ITS-2 rDNA marker sequences that were obtained through ML and BI produced well-defined trees, but with different topologies (Figures 2 and 3). The phylogenetic tree for the marker COI revealed that L. viator forms a sister group with L. neotropica and L. (Galba) cubensis, while the tree for the ITS-2rDNA marker showed that L. neotropica forms a sister group with L. viator and L. (Galba) cubensis. 


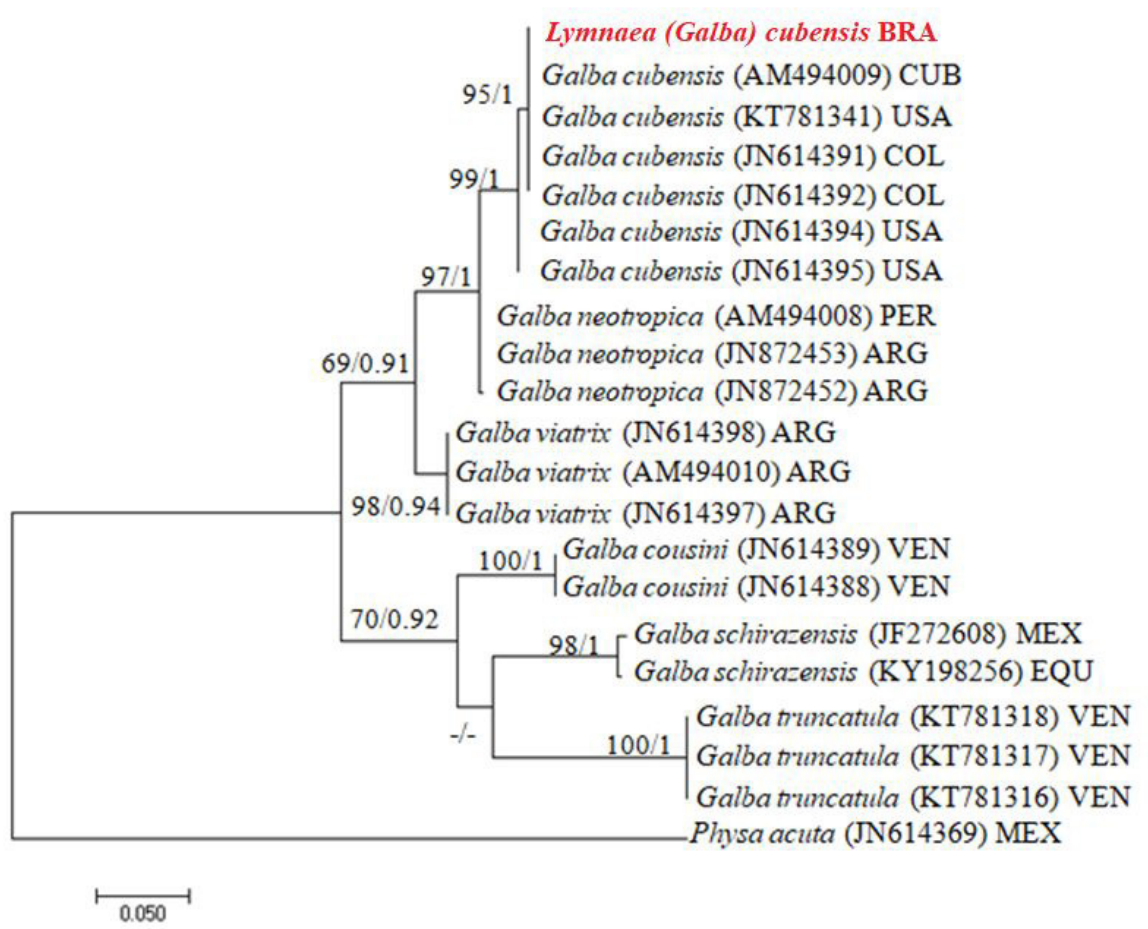

Figure 2. Phylogenetic relationships between Lymnaea (Galba) cubensis from Brazil (bold and red) and other species occurring in the neotropical region, inferred from partial mtDNA sequences of mitochondrial cytochrome c oxidase subunit I (COI) (609 bp alignment), based on Bayesian inference (BI) and maximum likelihood (ML). Nodal support is indicated as $\mathrm{ML} / \mathrm{BI}$; values $<0.90$ $(\mathrm{BI})$ and $<50$ (ML) are indicated by a dash. Physa acuta was inserted as an outgroup. Abbreviations: ARG - Argentina; BRA - Brazil; COL - Colombia; CUB - Cuba; EQU - Ecuador; MEX - Mexico; PER - Peru; USA - United States; VEN - Venezuela.

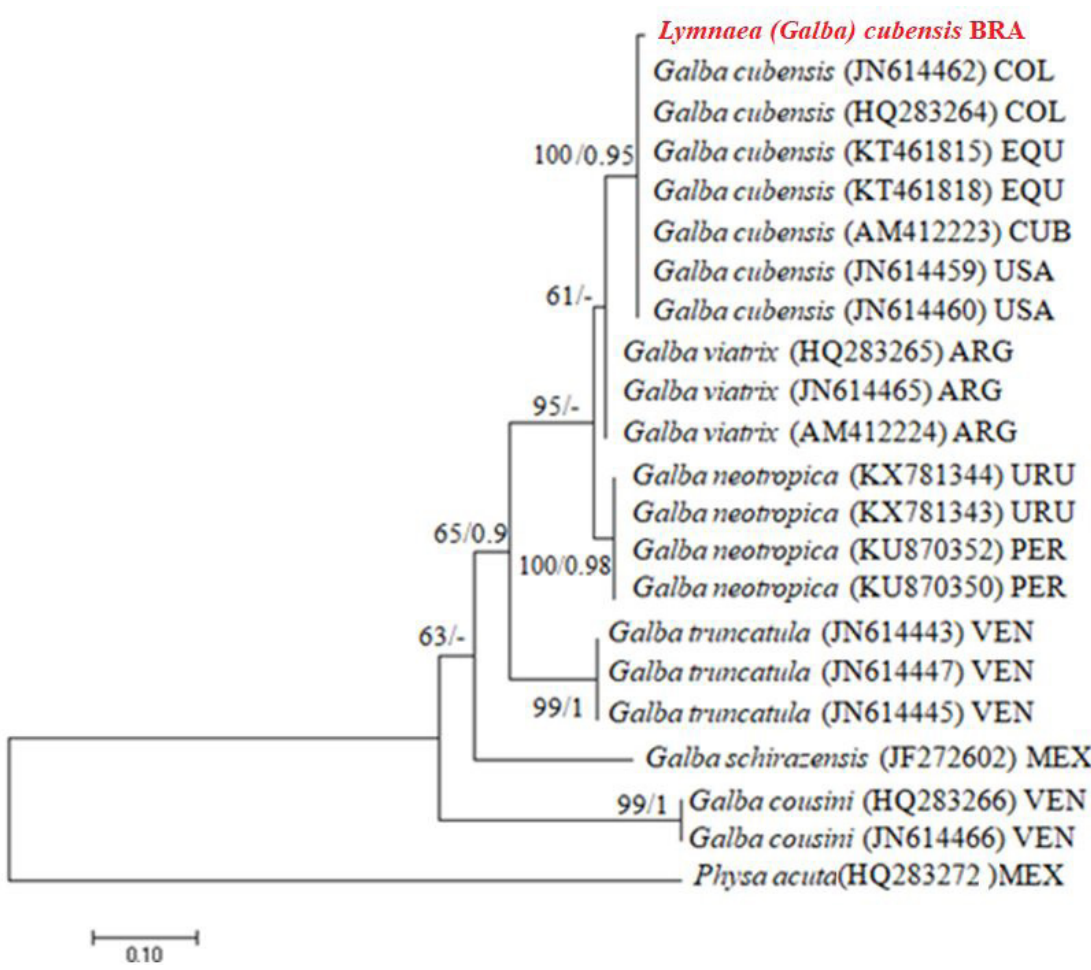

Figure 3. Phylogenetic relationships between Lymnaea (Galba) cubensis from Brazil (in bold and red) and other species occurring in the neotropical region, inferred from partial rDNA sequences of the ribosomal internal transcript spacer region II (448 bp alignment), based on Bayesian inference (BI) and maximum likelihood (ML). Nodal support is indicated as $\mathrm{ML} / \mathrm{BI}$; values $<0.90$ $(\mathrm{BI})$ and $<50$ (ML) are indicated by a dash. Physa acuta was inserted as an outgroup. Abbreviations: ARG - Argentina; BRA - Brazil; COL - Colombia; CUB - Cuba; EQU - Ecuador; MEX - Mexico; PER - Peru; USA - United States; VEN - Venezuela. 


\section{Discussion}

This was the first study reporting on findings of the lymneid Lymnaea (Galba) cubensis in Lagoa Santa, Minas Gerais, Brazil, using a combination of morphological and molecular features. In Cuba, the most compatible intermediate host for F. hepatica is L. (Galba) cubensis, given that both natural and experimental infections have been recorded by Vázquez et al. (2015). In Brazil, P. columella is considered to be the intermediate host of greatest epidemiological importance, due to its widespread distribution throughout the country. Moreover, it is found naturally infected with $F$. hepatica in areas where bovine fasciolosis occur (Dracz et al., 2016).

The length of the shell, the oval shape of the opening and the opening/length ratio are homogeneous characteristics, especially in G. truncatula, L. viator, L. neotropica and L. (Galba) cubensis (Samadi et al., 2000; Correa et al., 2011). In contrast, evident morphological differences present in the shell of $P$. columella allow it to be distinguished from other molluscs lymneids The main differences observed are that the opening/length ratio of P. columella is approximately 2:3 (Paraense, 1982a) and that it has a shallow suture, expanded last body loop and bright periostracum (Baker, 1908). The shells of molluscs of the genus Galba present convex turns, deep sutures and an opening/length ratio of 1:2 (Paraense, 1982a). Although morphological analysis on shells is of limited practical use for distinguishing the species of other genus, it allowed identification of the lymneid $P$. columella.

Differences regarding the lymneids' penile complex and prostate shape allowed to distinguish the L. (Galba) cubensis from the $G$. truncatula species The differences observed were the triangular prostate developed and little difference in the foreskin length in relation to the penis sheath. Indeed, the foreskin in G. truncatula is about two-thirds larger than the penis sheath and the prostate is bulbous and conical. Samadi et al. (2000) showed that in G. truncatula and L. (Galba) cubensis there is great variability in the anatomical characteristics of the male reproductive system, such as prostate size and the relationship between the foreskin and the penis sheath. This allows these species to be differentiated regardless of their geographical origin.

In the scientific literature, there is a consensus that the internal anatomy of the reproductive tract of $L$. (Galba) cubensis, L. viator and L. neotropica is homogenous, given that these are considered to be cryptic species (Paraense, 1976; Samadi et al., 2000; Correa et al., 2010). Therefore, Correa et al. (2011) suggested that molecular tools should be used to characterize species and their phylogenetic relationships. Through integrative taxonomy, we identified that the lymneid samples collected in Lagoa Santa, Minas Gerais, belonged to the species Lymnaea (Galba) cubensis, which was originally described by Pfeiffer (1839) in Cuba. Analysis on the nucleotide sequences of the mtDNA COI gene [GenBank: AM494009] and rDNAITS-2 [GenBank: AM412223] showed 100\% and 97.3\% similarity, respectively, with $L$. (Galba) cubensis from the region where the type locality was probably described (Bargues et al., 2007). The first record of $L$. (Galba) cubensis in Brazil that was found using PCR-RFLP was from a mollusc isolated in Belo Horizonte, Minas Gerais (Medeiros et al., 2014).

Through considering morphological characteristics alone, Rezende et al. (1973) had previously identified L. (Galba) cubensis in the state of Rio de Janeiro, in the municipalities of Três Rios, Paraíba do Sul, Petrópolis and Teresópolis, Brazil. However, Gomes \& Serra-Freire (2001) questioned the validity of this record because this species had never been found in these municipalities previously. Unfortunately, those studies did not present the geographical coordinates of the sampling points, which makes it difficult to localize these specimens in order to elucidate this question. As proposed by Bargues et al. (2012), if the specimens used in the present study had not been subjected to molecular analysis, they could have been mistakenly identified as L. neotropica or L. viator. Therefore, we suggest that the process of identifying lymneids needs to be reviewed, especially in the case of Brazilian studies that evaluate their participation in the life cycle of $F$. hepatica.

There is a consensus in the scientific literature that the nucleotide sequences ITS-2, ITS-1, 18S and COI are useful markers for differentiation of L. (Galba) cubensis, L. viator, L. neotropica and G. truncatula (Bargues \& Mas-Coma, 2005; Bargues et al., 2007; Correa et al., 2011). The difference in phylogenetic tree topology for the COI marker, showing L. viator as a sister group for L. neotropica and L. (Galba) cubensis, is consistent with the observations by Correa et al. (2011). Their DNA ITS-2 marker revealed that L. neotropica formed a sister group with L. viator and L. (Galba) cubensis, as suggested by Bargues et al. (2007).

Existence of co-specificity between L. (Galba) cubensis, L. viator and L. neotropica is a hypothesis that has previously been suggested in the literature (Correa et al., 2011; Lounnas et al., 2017). However, this hypothesis needs to be better evaluated, given that these species might be recently divergent taxa. Studies on the genetic definition of these species based on large samples from different geographical regions are also needed. Barcode analysis on the COI marker, considering a cutoff value of 6\%, showed this co-specificity (Correa et al., 2011). In the present study, considering a cutoff value of $4 \%$ for COI, L. (Galba) cubensis and L. neotropica were co-specific, but distinct 
from L. viator. When the analysis included ITS-2 the opposite result was found, L. (Galba) cubensis and L. viator were co-specific, but distinct from L. neotropica. Therefore, our study shows that combinations of phylogenetically informative markers such as COI and ITS-2 allow differentiation of these cryptic species.

The limitations and divergences in the use of a cut off value for the analysis of genetic distance in mtDNA, result from the fact that there is no genetic delimitation in these cryptic species of limneids. Therefore, it is difficult to establish a value that does not cause excessive divisions or groupings of species and as is well remembered by Correa et al. (2011) studies should be carried out on the sequencing of phylogenetically informative genes, carrying out appropriate phylogenetic analyzes based on large samples and the delimitation of species.

Although molecular tools are useful for species identification, lymneid systematics are recognized to be controversial. Schniebs et al. (2018) suggested that a broad taxonomic review of L. (Galba) cubensis, L. viator and L. neotropica should be undertaken, given that corrections to the classification of sequences available in GenBank are likely to be required.

\section{Conclusions}

Given the evidence laid out above, we conclude that the morphological and conchological characteristics of the L. (Galba) cubensis, L. viator and L. neotropica are homogeneous and provide little information that can properly identify molluscs of this species. Approaches based on ribosomal and mitochondrial DNA analysis for lymneid identification are tools of greater reliability. Correct differentiation between species of lymneids is important for enabling recognition and mapping of epidemiological risk areas in the state of Minas Gerais, given that the numbers of fasciolosis cases have been gradually increasing over recent years, in several regions of the state.

\section{References}

Alda P, Lounnas M, Vázquez AA, Ayaqui R, Calvopiña M, Celi-Erazo M, et al. A new multiplex PCR assay to distinguish among three cryptic Galba species, intermediate hosts of Fasciola hepatica. Vet Parasitol 2018; 251: 101-105. http://dx.doi.org/10.1016/j. vetpar.2018.01.006. PMid:29426464.

Armúa-Fernandez MT, Castro O, Correa O, Carvalho L, Mangold A, Sanchís J, et al. Primera caracterización molecular de Galba neotropica en Uruguay. Revista FAVE 2016; 15(1-2): 9-13. http://dx.doi.org/10.14409/favecv.v15i1/2.5978.

Baker FC. Suggestions for a natural classification of the family Lymnaeidae. Science 1908; 27(703): $942-943$.

Bargues MD, Artigas P, Khoubbane M, Mas-Coma S. DNA sequence characterisation and phylogeography of Lymnaea cousini and related species, vectors of fascioliasis in northern Andean countries, with description of L. meridensis $\mathrm{n}$. sp. (Gastropoda: lymnaeidae). Parasit Vectors 2011; 4(1): 132. http://dx.doi.org/10.1186/1756-3305-4-132. PMid:21749718.

Bargues MD, Artigas P, Khoubbane M, Ortiz P, Naquira C, Mas-Coma S. Molecular characterisation of Galba truncatula, Lymnaea neotropica and L. schirazensis from Cajamarca, Peru and their potential role in transmission of human and animal fascioliasis. Parasit Vectors 2012; 5(1): 174. http://dx.doi.org/10.1186/1756-3305-5-174. PMid:22894178.

Bargues MD, Artigas P, Mera y Sierra RL, Pointier JP, Mas-Coma S. Characterisation of Lymnaea cubensis, L. viatrix and L. neotropica n. sp., the main vectors of Fasciola hepatica in Latin America, by analysis of their ribosomal and mitochondrial DNA. Ann Trop Med Parasitol 2007; 101(7): 621-641. http://dx.doi.org/10.1179/136485907X229077. PMid:17877881.

Bargues MD, Mas-Coma S. Reviewing lymnaeid vectors of fascioliasis by ribosomal DNA sequence analyses. J Helminthol 2005; 79(3): 257-267. http://dx.doi.org/10.1079/JOH2005297. PMid:16153320.

Boray JC. Experimental fascioliasis in Australia. Adv Parasitol 1969; 7: 95-210. http://dx.doi.org/10.1016/S0065-308X(08)60435-2. PMid:4935272.

Correa AC, Escobar JS, Durand P, Renaud F, David P, Jarne P, et al. Bridging gaps in the molecular phylogeny of the Lymnaeidae (Gastropoda: Pulmonata), vectors of Fascioliasis. BMC Evol Biol 2010; 10(1): 381. http://dx.doi.org/10.1186/1471-2148-10-381. PMid:21143890.

Correa AC, Escobar JS, Noya O, Velásquez LE, González-Ramírez C, Hurtrez-Boussès S, et al. Morphological and molecular characterization of Neotropic Lymnaeidae (Gastropoda: Lymnaeoidea), vectors of fascioliasis. Infect Genet Evol 2011; 11(8): 19781988. http://dx.doi.org/10.1016/j.meegid.2011.09.003. PMid:21968212.

Dracz RM, Lima WS. Autochthonous infection of buffaloes and cattle by Fasciola hepatica in Minas Gerais, Brazil. Rev Bras Parasitol Vet 2014; 23(3): 413-416. http://dx.doi.org/10.1590/S1984-29612014054. PMid:25271466. 
Dracz RM, Ribeiro VMA, Pereira CAJ, Lima WS. Occurrence of Fasciola hepatica (Linnaeus, 1758) in capybara (Hydrochoerus hydrochaeris) (Linnaeus, 1766) in Minas Gerais, Brazil. Rev Bras Parasitol Vet 2016; 25(3): 364-367. http://dx.doi.org/10.1590/ S1984-29612016021. PMid:27096531.

Folmer O, Black M, Hoeh W, Lutz R, Vrijenhoek R. DNA primers for amplification of mitochondrial cytochrome c oxidase subunit I from diverse metazoan invertebrates. Mol Mar Biol Biotechnol 1994; 3(5): 294-299. PMid:7881515.

Gomes DC, Serra-Freire NM. Suscetibilidade de Lymnaea columella Say, 1817 à infecção por Fasciola hepatica L., 1758. R Bras Ci Vet 2001; 8(2): 121-126. http://dx.doi.org/10.4322/rbcv.2015.228.

Kane RA, Rollinson D. Repetitive sequences in the ribosomal DNA internal transcribed spacer of Schistosoma haematobium, Schistosoma intercalatum and Schistosoma mattheei. Mol Biochem Parasitol 1994; 63(1): 153-156. http://dx.doi.org/10.1016/01666851(94)90018-3. PMid:8183315.

Kimura M. A simple method for estimating evolutionary rate of base substitutions through comparative studies of nucleotide sequences. J Mol Evol 1980; 16(2): 111-120. http://dx.doi.org/10.1007/BF01731581. PMid:7463489.

Kumar S, Stecher G, Tamura K. MEGA7: Molecular Evolutionary Genetics Analysis version 7.0 for bigger datasets. Mol Biol Evol 2016; 33(7): 1870-1874. http://dx.doi.org/10.1093/molbev/msw054. PMid:27004904.

Lima WS, Soares LRM, Barçante TA, Guimarães MP, Barçante JMP. Occurrence of Fasciola hepatica (Linnaeus, 1758) infection in Brazilian cattle of Minas Gerais, Brazil. Rev Bras Parasitol Vet 2009; 18(2): 27-30. http://dx.doi.org/10.4322/rbpv.01802006. PMid:19602313.

Lounnas M, Vázquez AA, Alda P, Sartori K, Pointier J, David P, et al. Isolation, characterization and population-genetic analysis of microsatellite loci in the freshwater snail Galba cubensis (Lymnaeidae). J Molluscan Stud 2017; 83(1): 63-68. http://dx.doi. org/10.1093/mollus/eyw041.

Mas-Coma S, Valero MA, Bargues MD. Fasciola, lymnaeids and human fascioliasis, with a global overview on disease transmission, epidemiology, evolutionary genetics, molecular epidemiology and control.Adv Parasito/ 2009; 69: 41-146. http://dx.doi.org/10.1016/ S0065-308X(09)69002-3. PMid:19622408.

Medeiros C, Scholte RGC, D’avila S, Caldeira RL, Carvalho ODS. Spatial distribution of Lymnaeidae (Mollusca, Basommatophora), intermediate host of Fasciola hepatica Linnaeus, 1758 (Trematoda, Digenea) in Brazil. Rev Inst Med Trop São Paulo 2014; 56(3): 235-252. http://dx.doi.org/10.1590/S0036-46652014000300010. PMid:24879003.

National Center for Biotechnology Information - NCBI. [online]. 1988 [cited 2021 May 02] Available from: https://www.ncbi. nlm.nih.gov

Paraense WL. Lymnaea viatrix: a study of topotypic specimens (Mollusca, Lymnaeidae). Braz J Biol 1976; 36(2): 419-428.

Paraense WL. Lymnaea viatrix and Lymnaea columella in the Neotropical Region: a distributional outline. Mem Inst Oswaldo Cruz 1982a; 77(2): 181-188. http://dx.doi.org/10.1590/S0074-02761982000200008.

Paraense WL. Lymnaea rupestris sp. n. from Southern Brazil (Pulmonata: Iymnaeidae). Mem Inst Oswaldo Cruz 1982b; 77(4): 437443. http://dx.doi.org/10.1590/S0074-02761982000400011.

Paraense WL. Lymnaea columella in northern Brazil. Mem Inst Oswaldo Cruz 1983; 78(4): 477-482. http://dx.doi.org/10.1590/ S0074-02761983000400011.

Paraense WL. Lymnaea diaphana: a study of topotypic specimens (Pulmonata: Lymnaeidae). Mem Inst Oswaldo Cruz 1984; 79(1): 75-81. http://dx.doi.org/10.1590/S0074-02761984000100009.

Paraense WL. Lymnaea cousini Jousseaume, 1887, from Ecuador (Gastropoda: lymnaeidae). Mem Inst Oswaldo Cruz 1995; 90(5): 605-609. http://dx.doi.org/10.1590/S0074-02761995000500011.

Pfeiffer L. Bericht über die Ergebnisse meiner reise nach Cuba em Witer, Arch. Naturg 1839; 5: 346-358.

Rambaut A. FigTree [online graphical viwer program]. 2007. [ cited 2021 May 02] Available from: http://tree.bio.ed.ac.uk/software/ figtree

Reid F. Hydrochoerus hydrochaeris. The IUCN Red List of Threatened Species. Switzerland: IUCN; 2016. https://dx.doi.org/10.2305/ IUCN.UK.2016-2.RLTS.T10300A22190005.en.

Rezende HEB, Araujo JLB, Gomes PAC, Nuernberg S, Pimentel M, Oliveira GP, et al. Notas sobre duas espécies de Lymnaea Lamark, 1799, Hospedeiros intermediários de Fasciola hepatica no estado do Rio de Janeiro (Mollusca, Gastropoda, Basommatophora, Lymnaeidae). Arq Univ Fed Rural 1973; 3(1): 21-23.

Ronquist F, Teslenko M, van der Mark P, Ayres DL, Darling A, Höhna S, et al. MrBayes 3.2: efficient Bayesian phylogenetic inference and model choice across a large model space. Syst Bio/ 2012; 61(3): 539-542. http://dx.doi.org/10.1093/sysbio/sys029. PMid:22357727. 
Samadi S, Roumegoux A, Bargues MD, Mas-Coma S, Yong M, Pointier JP. Morphological studies of lymnaeid snails from the human fascioliasis endemic zone of Bolivia. J Molluscan Stud 2000; 66(1): 31-44. http://dx.doi.org/10.1093/mollus/66.1.31.

Sanger F, Nicklen S, Coulson AR. DNA sequencing with chain-terminating inhibitors. Proc Natl Acad Sci USA 1977; 74(12): 54635467. http://dx.doi.org/10.1073/pnas.74.12.5463. PMid:271968.

Schniebs K, Glöer P, Quiñonero-Salgado S, Lopez-Soriano J, Hundsdoerfer AK. The first record of Galba cubensis (L. Pfeiffer, 1839) (Mollusca: Gastropoda: Lymnaeidade) from open fields of Europe. Folia Malacol 2018; 26(1): 3-15. http://dx.doi.org/10.12657/ folmal.026.002.

Standley CJ, Prepelitchi L, Pietrokovsky SM, Issia L, Stothard JR, Wisnivesky-Colli C. Molecular characterization of cryptic and sympatric lymnaeid species from the Galba/Fossaria group in Mendoza Province, Northern Patagonia, Argentina. Parasit Vectors 2013; 6(1): 304. http://dx.doi.org/10.1186/1756-3305-6-304. PMid:24499569.

Vázquez AA, Sánchez J, Alba A, Pointier JP, Hurtrez-Boussès S. Natural prevalence in Cuban populations of the lymnaeid snail Galba cubensis infected with the liver fluke Fasciola hepatica: small values do matter. Parasitol Res 2015; 114(11): 4205-4210. http://dx.doi.org/10.1007/s00436-015-4653-2. PMid:26250985.

Vidigal THDA, Kissinger JC, Caldeira RL, Pires ECR, Monteiro E, Simpson AJG, et al. Phylogenetic relationships among Brazilian Biomphalaria species (Mollusca: Planorbidae) based upon analysis of ribosomal ITS2 sequences. Parasitology 2000; 121(Pt 6): 611-620. http://dx.doi.org/10.1017/S0031182000006831. PMid:11155932. 